\title{
BETWEEN CRITICISM AND PRAISE: PROVINCIALS' IMAGE OF THE GOVERNOR IN THE LATER ROMAN EMPIRE*
}

By

\author{
DANIELLE SLOOTJES
}

\begin{abstract}
"With fortunate omens have you come from the emperor, brilliant as a ray of the sun that appears to us on high. Thus a favorable report long ago brought word of your fortunate arrival and the most enviable lot of your subjects".
\end{abstract}

For centuries, provincial communities in the Roman Empire dealt with the presence of governors, which created a certain expectation in behavior, both for provincials and for governors themselves. My purpose is to take a closer look at the relationship between the two in the period of the Later Roman Empire, with a focus on the provincials' perspective: how far can we determine their attitude toward the governor, how did they show appreciation or criticism - of his actions, how did they portray him? Did the governor, indeed, appear 'brilliant as a ray of the sun'? These concerns contribute to a broader study I am currently conducting on the representation of the governor in the Later Roman Empire, based on a wide range of source materials, literary, epigraphic, artistic. In this paper, however, I limit myself to literary sources, in particular the works of Menander Rhetor and Libanius. I also concentrate on criticism, because I have found that those who criticize the governor exploit the same themes as those who praise him, and because it clearly seems possible to determine provincials' expectations through their criticisms. I introduce some sections from Libanius, which are notably revealing in this respect. The last part of the paper focuses on how Libanius' criticism illuminates an important part of the character and rhythm of provincial life.

Before criticism, the concept of praise needs to be discussed briefly, because in my argument the two are closely connected. During the governor's

\footnotetext{
*This paper was originally given at the third Workshop of the Network 'Impact of Empire' (Rome, March 2002). Many thanks to the Network and in particular Prof. Lukas de Blois for offering me the opportunity to contribute. Special thanks to Prof. Richard Talbert for his valuable suggestions.

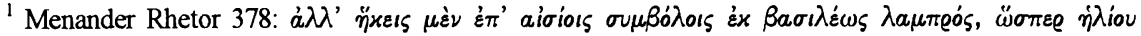

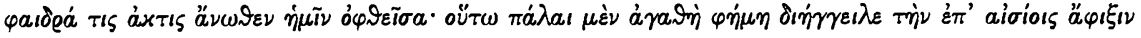

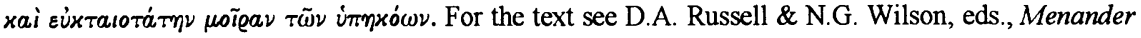
Rhetor (Oxford 1981). The translations throughout this paper are based on their edition as well, with some changes where appropriate.
} 
stay there were several occasions on which provincials would have a chance to honor him with a speech of praise, for example, on his arrival, or in gratitude for benefactions he had bestowed on a city, or because he was celebrating a festival there. Speeches for governors were part of a series of rituals designed to establish a relationship between the person who was welcomed or praised and those who welcomed and praised him. Not only did the words of a speech honor the governor, they also defined his position. ${ }^{2}$

The common themes of praise are well laid out by Menander Rhetor (PLRE I 595), an orator and teacher of rhetoric in the late third century. In his instructions for two of his speeches to a governor (the speech of arrival: $\delta$

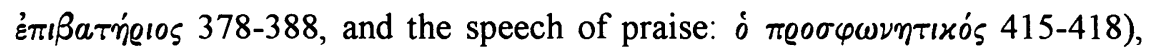
he recommends the following elements: expression of joy at the governor's arrival or presence; praise of his family, education, deeds and virtues; and a general comparison to characterize him as being far superior to everybody else. ${ }^{3}$ These common themes of praise, I argue, also appear in criticism.

In the works of Libanius (PLRE I 505-507) there are remarkable examples of reproaches to a governor for his lack of ability to govern. For instance, the Speeches 45 ('To the emperor, on the prisoners') and 33 ('To the emperor Theodosius, against Tisamenes') -dated to the late $380 \mathrm{~s}-$ are paired together in modern scholarship, because both address the conditions in the prisons, and demonstrate a negative view of governors. According to Libanius, prisons in Antioch were overcrowded, because governors were too slow in fulfilling their judicial functions as well as in executing those sentenced to death.

Both speeches address the emperor. Speech 33 is specifically directed against Tisamenes (PLRE I 916-917), who was governor (consularis) of Syria in 386. Libanius hoped to get the emperor's support in removing him, because of his inability in office. He starts by expressing frustration instead of the customary joy and excitement over the presence of the governor. $\mathrm{He}$ is clearly aware that in a speech for the governor praise was usually expected, and he appears apologetic that this will not be the case here, for he will take the opposite approach: "Ideally, Sire, everyone sent out to the government of the provinces should be so good that I should be able to say something better

\footnotetext{
${ }^{2}$ S. Price, Rituals and Power. Roman Imperial Cult in Asia Minor (Cambridge 1984), 7-8.

${ }^{3}$ Menander gives instructions for two other types of speeches for governors: the speech of invitation: $\mathrm{K} \lambda \dot{\eta}^{\prime} \iota$ เко (424-430), and the speech in 'talk' form: $\Lambda a \lambda ı \dot{a}(388-394)$.
} 
about Tisamenes. Indeed, my preference is not so much to speak ill of him as the reverse." 4

He briefly discusses Tisamenes' family background, explaining that, although he came from a respectable family, and was on course for a good education, he suddenly decided to head for the less respected life of dancing. ${ }^{5}$ As Menander Rhetor advises, in a speech of praise, to mention good family background and good education was important, because it would show that the governor was a respectable and sophisticated person. ${ }^{6}$ To state the opposite about the governor as Libanius does here, sets the tone for his negative portrayal and assessment of Tisamenes. Libanius' slant makes Tisamenes' situation seem even worse, because he did, in fact, come from a respectable family and had started a good education until, evidently, he decided to head into the wrong direction. The ideal of a respectable and sophisticated governor is tellingly reversed in this image of Tisamenes.

Jurisdiction was one of the governor's most important and timeconsuming activities. In a speech of praise, when discussing the virtue of justice, one would emphasize that the governor had a sense of humanity toward his subjects, was uncorrupt, free from partiality and prejudice in his judicial decisions, and treated the rich and poor equally. ${ }^{7}$ Fair treatment of the poor is a recurring theme in other sources; the jurist Ulpian, for example, stressed it when he explained the duties of the governor. ${ }^{8}$ Libanius demonstrates the opposite in Tisamenes, who allegedly has a total lack of interest in court cases and, when he must hear them, no determination in bringing them to an end. Tisamenes is represented as a governor who would

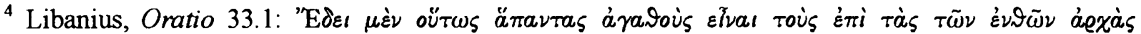

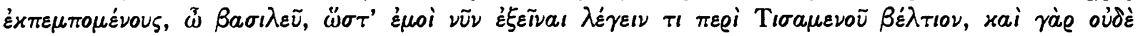

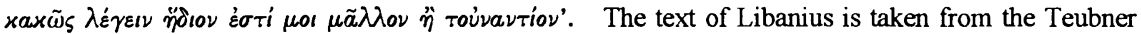
edition by R. Foerster, ed., Libanii Opera (Stuttgart 1906). The translations are based on the Loeb translations by A.F. Norman (Cambridge (MA)/London 1977), with changes where appropriate.

${ }^{5}$ Libanius, Oratio 33. 3.

${ }^{6}$ Menander Rhetor 379-381 and 415-416.

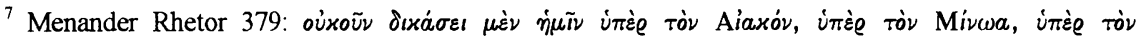

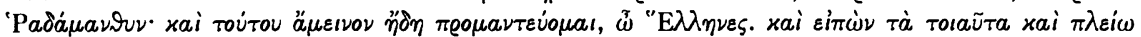
$\pi \varepsilon \rho i$ dıxaı

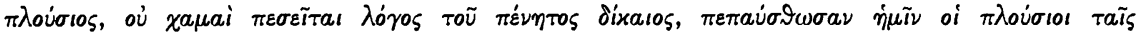

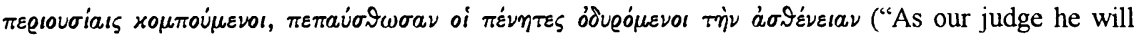
outclass Aeacus, Minos, or Rhadamanthus -nay, men of Hellas, I prophesy he will do better than this..." These and similar remarks may be made on the theme of justice: "No one will dwell in prison unjustly, or be unjustly punished; the rich will not be preferred, nor the poor man's just cause fall on the ground. So let our rich men cease to boast of their resources and our poor cease to complain of their weakness.")

${ }^{8}$ Dig. 1.16.7.
} 
prefer to be at a public entertainment, "he shunned courts; hankered after invitations to the hippodrome and the theatre" (33.8), while he should be concerned with justice in court: "he is the greatest stumbling-block to the administration of justice", because he is "incapable of seeing where justice lies and refusing to keep his mouth shut. He burbles in a pointless flood of words so as to distress the ears and weary the feet of the lawyers" (33.9). ${ }^{9}$ Again, praise and criticism are opposite sides of the same coin; the reverse rhetoric from Libanius' speech shows the same expectation about the governor's conduct in fulfilling his judicial responsibilities: provincials are hoping for a governor who is fair and competent in court, a governor who is, as Menander states it, "above gain and pleasure". ${ }^{10}$

Tisamenes' lack of ability is not confined to judicial irresponsibility. With regard to tax collection, the second main duty of the governor, Libanius accuses him of asking for the taxes too early and of consciously trying to hurt the provincials. He even publicly calls him a laughable fool:

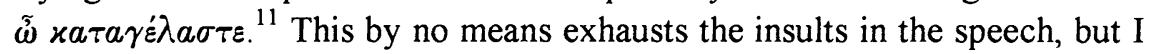
want to proceed to some general features of provincial government, which set the speech in context.

As a member of the curial class of Antioch, Libanius is not necessarily representing the view of the whole provincial population. Nevertheless, he still reveals some of their expectations in the way he expresses his anger and frustration at the governor's misbehavior. We could call this a mirror image of what the governor should be, of the provincials' expectations, and of what Menander recommends. Every negative comment, when turned into the positive, is a reflection of provincials' hopes. Menander too acknowledged this possible function of negativity, when he stated that in a speech of welcome it is permissible to give a vivid portrayal of bad treatment by the former governor, for this will be an encouragement to the

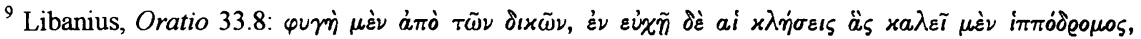

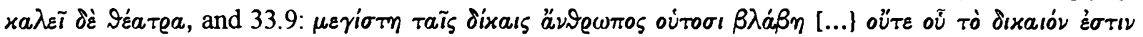

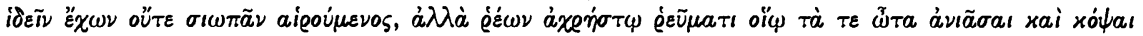

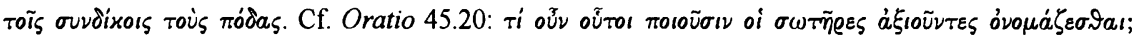

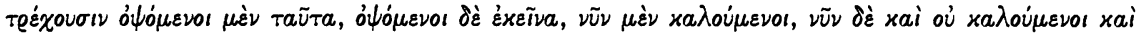

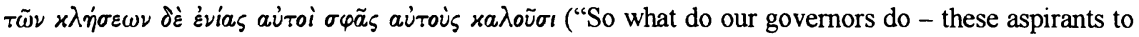
the title of 'saviors'? They hurry to see first this show, then that, sometimes by invitation, sometimes not, sometimes actually self-invited, for obviously they are self-invited when they personally ensure that the future hosts flock to their doors").

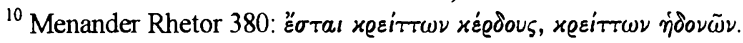

${ }^{11}$ Libanius, Oratio 33.19.
} 
new governor to act differently. ${ }^{12}$ By the same token, many of the praises recommended by Menander are designed to direct and inspire the governor to rule well.

While there is not much evidence of open rebukes to a governor, the speech against Tisamenes is not an isolated case. There are others by Libanius himself. ${ }^{13}$ In the early fifth century there is a notable example in the work of Synesius, bishop of Cyrene (PLRE II 1048-1050), who wrote against the new governor of Libya Superior, Andronicus of Berenice (PLRE II 89-90), because his appointment had allegedly been illegal. ${ }^{14}$ Synesius, like Libanius, offered a negative portrayal of the governor in regard to his family background, education and sense of justice, and Andronicus emerged as a pest, a wicked ruler destructive to his province. ${ }^{15}$ Synesius' work is instructive, because it presents a clash between a bishop and a governor. Ever since the official adoption of Christianity by Theodosius the Great (379-395), bishops had gained a key role in provincial communities. ${ }^{16}$ Hence, they started to interfere with the governor's business, and inevitably the two parties would clash. ${ }^{17}$

The obvious first place in the Later Empire to express provincial grievances and ask for requests was the provincial council. It continued to function as a representative body, discussed matters of provincial interest, and sent delegations to the vicar or praetorian prefect, who could in turn refer them to the emperor. ${ }^{18}$ The situation of Libanius is rather exceptional,

12 Menander Rhetor 378: “... and amplify their hardships, not, however, speaking ill of the predecessor, but simply reporting the subjects'misfortune. Then go on: "When night and darkness covered the world, you were seen like the sun, and at once dissolved all the difficulties'."

${ }^{13}$ Cf. Libanius, Oratio 57, against Severus; Oratio 1, 26, 27, 28 and 29, all containing negative statements against Icarius; Oratio 44 and 54, Libanius attacking Eustathius for not treating Libanius with sufficient respect.

${ }^{14} \mathrm{CJ} 1.41$; no man was allowed to become governor of his province of his birth. By 610 this law was ignored and governors were often natives of the area they governed. See also J.H.W.G. Liebeschuetz, Fall and Decline of the Roman City (Oxford 2001), 279.

${ }^{15}$ See Synesius, Epistula 41, 42, 72, 73, 79, and 90, edited by.A. Garzya, Synesii Cyrenensis Epistolae (Rome 1979).

${ }^{16}$ A.H.M, Jones, The Later Roman Empire 284-602 (Baltimore 1964), 165.

${ }^{17}$ See Liebeschuetz 2001, op.cit. (n. 14), 152. The emperor Justinian (527-565) made it part of the bishop's duty to supervise the governor. Upon entering the province, a new governor had to take an oath in presence of the metropolitan bishop and leading citizens (Novella 8.14). Furthermore, Justinian invited the bishop and leading citizens to bring complaints about the governor to the attention of the emperor. If a citizen could not get justice from the governor, he was to take his matter to the bishop who would take every step to see that justice was done, with the last resort of informing the emperor.

${ }^{18}$ The following law from 382 illustrates that the provincial council was still regarded as an accepted institution for dealing with provincials' business: CTh 12.12.9, ad provinciales: Sive integra dioecesis in commune consulerit sive singulae inter se voluerint provinciae convenire, nullius iudicis potestate 
in that he claims a more direct link to the emperor; both speeches (45 and 33) addressed him, and he states that the emperor would expect him to criticize the governor. In Speech 45 he says: "You (the emperor) will ask, "How can it be that you (Libanius) have neglected this, when you should reprove the governors and tell them what you are telling me now, and not allow them to be slack, even if they want to be?" ${ }^{19}$ Emperors were concerned about their subjects, and at the same time wanted to know what their governors and other officials were doing. In 331, Constantine the Great (312-337) even ordered that written records of the acclamations of the provinces had to be sent to the emperor for review. ${ }^{20}$ As 'semi-spontaneous'

tractatus utilitati earum congruus differatur ("If an entire diocese should consult in common, or if separate provinces should wish to meet with each other, by the power of no judge shall any discussion be deferred if it is suitable to their advantage", text by Th. Mommsen \& P. Meyer (Berlin 1905), and translation by C. Pharr (New York 1952). Cf. Ammianus Marcellinus 28.6.7 for a reference to the annual meeting of the provincial council in Tripolis.

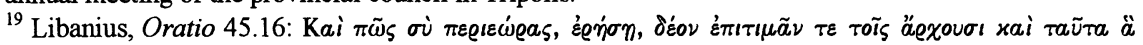

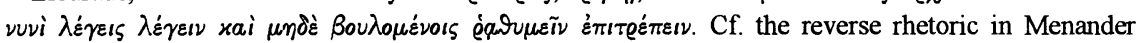
Rhetor 417-418: "Let us compose decrees to send to the emperors in praise and admiration, and in prayer for many years of his (governor's) rule. Let us send statues to Delphi, to Olympia, to Athens first however filling our own cities with them. Let him be depicted with his subject people all around him, all giving thanks and applauding. Let cities lead the procession in the picture, represented as women, bright-faced and rejoicing".

${ }^{20} \mathrm{CTh} 1.16 .6$, ad provinciales (= CJ 1.40.3): iustissimos autem et vigilantissimos iudices publicis adclamationibus conlaudandi damus omnibus potestatem, ut honoris eis auctiores proferamus processus, e contrario iniustis et maleficis querellarum vocibus accusandis, ut censurae nostrae vigor eos absumat; nam si verae voces sunt nec ad libidinem per clientes effusae, diligenter investigabimus, praefectis praetorio et comitibus, qui per provincias constituti sunt, provincialium nostrorum voces ad nostram scientiam referentibus, ("we grant to all persons the privilege of praising by public acclamation the most just and vigilant judges, so that We may grant increased accessions of honor to them. On the contrary, the unjust and the evildoers must be accused by cries of complaints, in order that the force of Our censure may destroy them. For we shall carefully investigate whether such utterances are truthful and are not poured forth effusively and wantonly by clients. The praetorian prefects and the counts who have been stationed throughout the provinces shall refer to Our Wisdom the utterances of Our provincials"). Cf. CTh 12.12 .9 of 382 ad provincials: sicut licere columus oppressis deflere quae perferunt, ita provinciales nostri nec incassum peregrinationem suscipiendam eaque ad sacras aures deferenda cognoscant, quae probabiliter principibus adserantur nec superfluis perennitatem nostram existiment actibus occupandam ("just as it is Our will that the oppressed provincials shall be permitted to lament their sufferings, so Our provincials shall know that they must not undertake such a pilgrimage in vain and that they must convey to Our sacred imperial ears those matters which may reasonably be alleged before the Emperor, and they must not suppose that Our Eternity should be besieged with superfluous transactions"). See also J.H.W.G. Liebeschuetz, Antioch. City and Imperial Administration in the Later Roman Empire (Oxford 1972), 209, and A. Cameron, Circus Factions. Blues and Greens at Rome and Byzantium (Oxford 1976), 241 for more discussion on the semi-constitutional status of acclamations. Cf. C. Roueché, 'Acclamations in the Later Roman Empire: New Evidence from Aphrodisias', Journal of Roman Studies 84 (1984), 181-199. 
expressions of a unanimous crowd, acclamations illustrate that provincials knew that demonstrations of negative sentiments were allowed. ${ }^{21}$

Any individual, even though he spoke on behalf of a community or a province, took a risk by exposing himself to the anger and possibly revenge of a governor, or the governor's supporters. Libanius himself shows his awareness of this risk when he states at the beginning of his speech 33: "now the person, whose many words and actions have secured him as our governor, will be annoyed at my remarks and will seek to do harm to the one who has provoked him, for his influence is all that he could wish it to be". ${ }^{22}$

Why, then, would Libanius even dare to speak negatively about the governor in public? For provincials to be upset about the governor's behavior was hardly a novelty of the Later Roman Empire. Under the Republic and the Principate provincials could, and did, accuse the governor of misconduct after his term of office in the repetundae courts or the senate. It seems, though, that even the latter court stopped functioning in the early third century, when we find the last known repetundae case under Septimius Severus. ${ }^{23}$ The Roman world was changing, and provincials needed to find other ways to express their frustration.

Several features of the Late Roman world perhaps acted to make it less 'perilous' to rebuke the governor openly during his term of office. First, the reforms of Diocletian (284-305) led to a new division into many more provinces, and a novel system of dioceses and prefectures, headed by vicars and praetorian prefects respectively. By breaking up the larger provinces and by creating separate military commanders (duces), Diocletian diminished the status of provincial governors. At the same time, many more men became

\footnotetext{
${ }^{21}$ By the fourth century, acclamations had become less spontaneous, and increasingly standardized and regulated, shouted according to certain rhythms. G.S. Aldrete, in Gestures and Acclamations in Ancient Rome (Baltimore 1999), 128-131, argues that the formulaic character of acclamations does not necessarily exclude flexibility, and proves his point with some examples of standard expressions of acclamations adapted into something completely different.

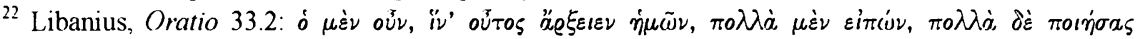

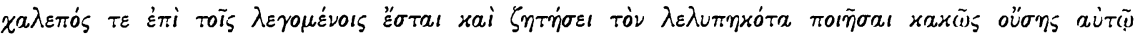

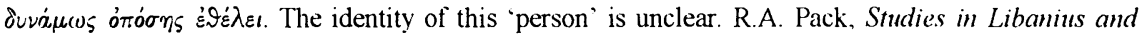
Antiochene Society under Theodosius (Diss. Michigan 1935), 96, has suggested that this 'person' is possibly Crnegius (PLRE I 235-236) the Praetorian Prefect of the Orient in the period 384-388, but Norman 1977, op.cit. (n. 4), 194 remains skeptical.

${ }^{23}$ See R.I.A. Talbert, The Senate of Imperial Rome (Princeton 1984), appendix 9, 510. Cf. P.A. Brunt, 'Charges of Provincial Maladministration under the Early Empire', in Idem, Roman Imperial Thentes (Oxford 1990), 53-95, with 487-506
} 
governors, because many more were needed. ${ }^{24}$ Consequently, other Roman officials - with more power than the governor and able to interfere with his business - became a permanent presence throughout the provinces. This inevitably caused a shift in the relationship between governors and provincials. He was less powerful, and provincials might feel less hesitant to criticize him, now that they could take their case to the vicar, or even to the praetorian prefect.

Further adjustments, too, were required of governors themselves from Diocletian's time onwards. Before, they were sent to govern provincials who mostly were of lower status than them selves. This had changed. The provincial elite was more and more the elite of the Empire, and often had valuable connections in Rome or Constantinople. Typically now, the governor came from the same class as the elite of the people he was governing, or even from a lesser one. As always, if the masses became upset with the governor, they might not be able to pursue their aggravation; but if wealthy upper class provincials with good connections were frustrated, they were better placed than ever to use their influence against the governor. In addition, to a provincial like Libanius -who belonged to the elite of the province and had established himself as a famous orator and patron of his city- the individual governor was of only temporary importance. Why fear him unduly? For the governor, the unpredictability of the length of his term in office did not help either. It was not fixed, and, Jones, based on the fasti of Africa and Egypt, has drawn the conclusion that on average the length of a governor's term of office was probably well under two years. ${ }^{25}$ Libanius also refers to the rapid turnover of governors: "nowadays, though, it is the man who has been able to buy office, who scurries in and keeps turning round to check whether his successor is hard on his heels". ${ }^{26}$ Such a relatively short term will have created tension for the governor, because of the "complexity of his

\footnotetext{
${ }^{24}$ C. Roueché, 'The Functions of the Roman Governor in Late Antiquity: Some Observations', Antiquité Tardive 6 (1998), 35. Most likely members of the provincial elite served as governors as well, because a larger number of governors were needed.

${ }^{25}$ Jones 1964, op.cit. (n. 16), 381-383. For Africa (in the period between 357-417) the average was little more than a year, and for Egypt (328-373, when the prefects of Egypt were mere provincial governors) well under two years, perhaps even 18 months.

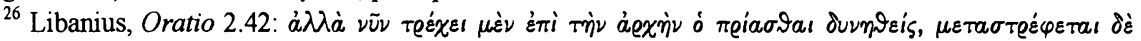

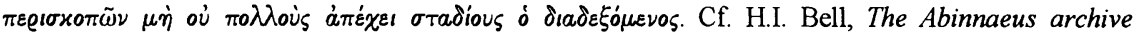
(Oxford 1962). Upon presenting the imperial letter with his appointment as the new commander of the praefectus alae at Dionysia to the count of Egypt, Abinnaeus (PLRE I 1-2) found that other men had claimed his office with similar letters. Even though he was not a governor, his story illustrates the unpredictability of public office.
} 
responsibilities" ${ }^{27}$ If time was short, it was practically impossible to focus on any long-term issues. However, it must be noted that short tenure was not a new feature of the Later Roman Empire. Under the Principate, governors of public provinces routinely had a term of only one year, and they ran into the same difficulty with long-term problems.

The question arises, if the office of governor had been so much devalued, why would anyone even want it, as many evidently did? One reason was financial gain, which was accompanied by the widespread phenomenon of corruption. ${ }^{28}$ Governors often spent lavishly to purchase the office, and during their term they tried to compensate for such expenditure. Another notable motive was to acquire permanent exemption from curial duties, one of the privileges for those who had held office. ${ }^{29}$

Provincials and governors were part of the same system, yet there was inevitably tension between them. In the end, though, each needed the other. If the governor demonstrated that he was serving the interests of provincials, they were willing to comply with him, and vice versa. If he fulfilled his duties according to their expectations, they praised him. If not, Libanius illustrates for us the possible reaction. The sharp closing words of his Speech 33 sum up the provincials' ideal:

"So free your cities of such ills and send us a man of sense, who is eager to work hard, a doer rather than a talker, and one who will use persuasion rather than compulsion, a helper of the poor rather than their oppressor, who will distinguish what is and what is not possible, and recognize a time for flogging and a time for threatening - in short, a man who is nothing at all like this plague here" ${ }^{30}$

\section{UNC Chapel Hill, March 2003}

\footnotetext{
${ }^{27}$ Roueché 1998, op.cit. (n. 24), 34.

${ }^{28}$ Cf. CTh 8.15.5, 8.15.6. Jones 1964, op.cit. (n. 16), 393-401. See R. MacMullen, Corruption and the Decline of Rome (New Haven/London 1988), especially 122-170 for a discussion of corruption and the

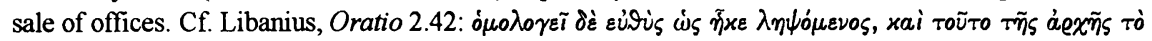

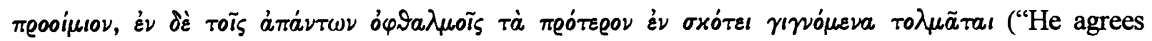
straightaway that he is there for what he can get; and this is the prelude to his term, and what previously used to be done under cover, is now ventured upon in full view of all and sundry").

${ }^{29}$ Jones 1964, op.cit. (n. 16), 536.

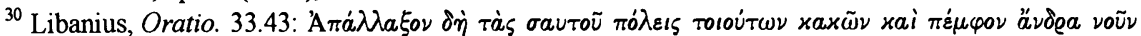

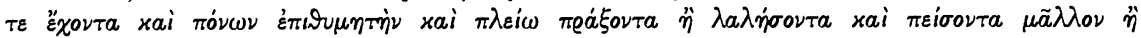

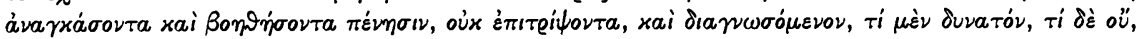

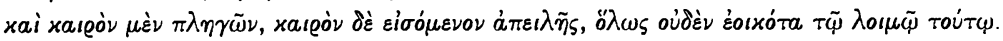

